\title{
Exploring Language Anxiety Regarding Speaking Skill in Iranian EFL Learners in an Academic Site in Malaysia
}

\author{
Ali Asghar Yousefi Azarfam (Corresponding author) \\ Department of English Language Education \\ Islamic Azad University of Iran, Soufian Branch \\ Soufian IAU, East Azarbayjan, Iran \\ E-mail: ali.youssefi8@gmail.com \\ Roselan Baki \\ Faculty of Educational Studies, Selangor, Malaysia \\ University Putra Malaysia, Malaysia
}

Received: 30-05- 2012

Accepted: 18-06- 2012

Published: 01-07- 2012

doi:10.7575/ijalel.v.1n.2p.153

URL: http://dx.doi.org/10.7575/ijalel.v.1n.2p.153

\begin{abstract}
This paper attempts to explore the language anxiety in speaking skill of Iranian EFL language learners from two different perspectives of language teachers and language learners. In doing so, it follows a qualitative method in the form of case study through in-depth semi-structured interviews with three experienced EFL teachers along with three EFL learners. Purposive sampling is conducted in order to choose these informants for the study. This research provided some alternative insights on language anxiety from two different perspectives. The results of the study showed that language anxiety could affect the speaking skills of learners by lowering the quality of oral performance as the anxiety increases. Further, as is clearly shown by the interview results, many of the accounts from the informants seem to generally validate the findings offered by earlier research on language anxiety. For instance, among the strategies to lower student anxiety in class is considered learner-centered approach that was agreed up on by both instructors and learners, but it is also maintained that there are some differences or gaps between the EFL teachers' and learners' perceptions on the role of anxiety in EFL classroom settings. Finally, based on the viewpoints of the EFL teachers and students there are suggested some strategies to confront, control, and alleviate anxiety in speaking of EFL learners.
\end{abstract}

Keywords: language anxiety; speaking skill; qualitative method; EFL teachers and learners

\section{Introduction}

Generally, there are two approaches to the explanation of language anxiety: first, language anxiety in the broader construct of anxiety as a basic human emotion that as McIntyre, (1995) claims may be brought on by numerous combinations of situational factors. For example, a shy student may feel anxious when asked to give a short talk in front of the whole class; second,as Horwitz, Horwitz and Cope (1986) put it language anxiety as a combination of other anxieties that create a separate form of anxiety intrinsic to language learning. This second trend believes that there is something unique to the language learning experience that makes some individuals nervous.

Hence, considering this language specific anxiety in EFL context, many learners say that they are unable to learn to speak a foreign language. They are probably good at learning other skills, but as Horwitz et al., (1986) say when it comes to learning to speak another language, they claim to have a 'mental block' against it.

With the beginning of communicative language teaching, English education in Iran the same as some other countries has been gradually changed to focusing on refining and improving communicative ability. Consequently, Iranian learners of English, especially in non-governmental sectors and English institutes are struggling to improve and advance their English communicative skills, particularly listening and speaking skills. In the meantime, affective variables in language learning have been arisen among which are anxiety and

Page $\mid 153$ 
International Journal of Applied Linguistics \& English Literature

ISSN 2200-3592 (Print), ISSN 2200-3452 (Online)

Vol. 1 No. 2; July 2012

self-confidence and self-esteem that Iranian EFL learners are encountering and suffering from in communicative language classroom.

Krashen, who was interviewed by Young (1992), asserted that speaking can cause high anxiety level and the reason for this is that teachers often expect beginners to perform beyond their acquired competence. In early phases, the instructor make learners break the silent period before they are ready and they have to use parts of language that they have not yet subconsciously acquired. Therefore, learners will show poor speaking performance because they are not skillful and competent in using the foreign language.

Language anxiety includes three connected performance anxieties: communication apprehension; test anxiety; and fear of negative evaluation. As Croskey (1977) believes because of its stress on interpersonal interaction, the construct of communication apprehension is quite relevant to the conceptualization of foreign language anxiety. It is a type of shyness characterized by anxiety about communication with people.

\subsection{Statement of the Problem}

This research, focusing on language specific anxiety from the perspective of performance anxieties, will try to explore in depth the frequently occurring type of performance anxiety which is communication apprehension. It seems to be occurring in all levels of learning, with no exception, from beginning to more advanced levels in our local EFL context, and the level of it is 'alarming' at academic sites and universities, and foreign language learners experience debilitating levels of it.

One shortcoming of the past research studies in this field could be the lack of viewpoints of instructors towards language anxiety, and it is observed that language anxiety has been explored basically from the learners' point of view, revealing the nature of anxiety that they may feel in language learning context. However, there is a specific need to address this phenomenon from teacher's viewpoint, especially as Young (1992) claims to the conceivable gaps between the teacher's views or assumptions on student anxiety and the students' actual psychological needs. Therefore, this study in addition to the viewpoints of language learners will take into account the EFL teachers views towards language anxiety.

\subsection{Research Objectives}

The research objectives of this study include the following: to find out why EFL learners feel anxious or embarrassed while learning to speak English language, to realize what influence anxiety casts on communication in target language, and finally to find out and suggest some strategies for language teachers in order to alleviate language anxiety in the learners.

\subsection{Research Questions}

Taking into account the objectives, the study comes up with some research questions which need to be answered by this qualitative research. The questions are as follow:

1. What are the factors concerning communication apprehension that cause language anxiety for EFL learners in learning to speak English language?

2. What are the EFL teachers' and learners' perceptions of language anxiety that is manifested in the learners?

3. Which strategies can be used both by teachers and learners to deal with language anxiety?

\section{Literature Review}

As said before in introduction, the focus of ESL/EFL instruction has moved from the narrow concern for developing learners' linguistic competence to the need for dealing with and enhancing the level of communicative competence. Hence, these learners are challenged to be able to speak in English spontaneously in various social contexts. In order to meet this challenge, attention has diverted to studying the role of affective variables like learning styles, motivation, personality traits, etc. that can impede the process of learning and speaking a foreign language. Among these affective variables, learner anxiety has come to be recognized as an important area of study in second language acquisition because of the negative influence it can have on students' performance.

Reviewing the past literature, you will see a body of research done about language anxiety mostly quantitatively. As some examples Gardner (1985), Gardner, Tremblay, and Masgoret (1997) in their studies found high correlation between the anxiety and the proficiency. That is, learners with low language anxiety will be successful in their second language learning. Learners with high anxiety, on the other hand, will not. In another study of 272 first-and second-year Japanese university students in Japan, Caprio (1987) found negative reactions Page | 154 


\section{International Journal of Applied Linguistics \& English Literature}

ISSN 2200-3592 (Print), ISSN 2200-3452 (Online)

Vol. 1 No. 2; July 2012

to being called on in class and speaking English. Hashimoto's (2002) study of 56 Japanese students at a university in the United States found that anxiety exerted a strong influence on perceived competence and negatively affected their willingness to communicate.

Young (1991) recognized six potential sources of language anxiety from three different aspects: the learner, the teacher, and the instructional practice. He claimed that language anxiety is caused by (a) personal and interpersonal anxiety, (b) learner beliefs about language learning, (c) instructor beliefs about language teaching, (d) instructor-learner interactions, (e) classroom procedures, and (f) language testing. Further, according to what Young (1991) says about language anxiety, erroneous learner beliefs about language learning can contribute greatly to creating language anxiety in students. As reported by some researchers, pronunciation is considered to be the most important aspect of foreign language learning by a lot of students. It is clear that these unrealistic beliefs by learners can lead to greater anxiety and frustration.

Within one study, Horwitz and her colleagues described the physiological and psychological symptoms of language anxiety, many of which occur in anxious states in general as tenseness, trembling, perspiring, palpitations, and sleep disturbances. Anxiety was also observed in language learners in such symptoms as freezing in class, going blank before exams, and feeling reticence about entering the classroom. The researchers noted how these learners experience apprehension, worry, even dread. As mentioned by the researchers they had difficulty concentrating, became forgetful, sweated, and had palpitations and they typically exhibited avoidance behavior such as missing class and postponing homework.

Once you have a look at the academic literature on language anxiety, you will come across a somewhat confusing account of it. There seems to be no full consensus among the researchers over the issue of sort of effect anxiety has on language learning and performance. Some scholars reported a negative relationship between language anxiety and success in language class, i.e. the higher the anxiety, the lower the performance, as claimed by Clement, Gardner, \&Smythe (1980). Others reported that there is no relationship, or a positive relationship (Backman, 1976, Scovel, 1978). More recently, Horwitz (2001) has claimed that the issue of understanding the relationship between anxiety and achievement is unresolved. As stated by Philip (cited in Shamas, 2006) the reason for these mixed results is conceivably that a comparison of the experimental research examining the relationship between anxiety and second language learning is, to a degree, perplexing, presenting some conflicting evidence and illustrating that anxiety is a complex, multi-faceted construct.

Horwitz et al. (1986) on the other hand, sketched parallels between language anxiety and three related performance anxieties: (1) communication apprehension; (2) test anxiety; and (3) fear of negative evaluation. Since the focus in this study is on speaking skills, the major component communication apprehension will be dealt with in the research.

Horwitz et al. (1986: 128) define communication apprehension (CA) as "a type of shyness characterized by fear or anxiety about communicating with people". According to Croskey (1987), comprehension apprehension, which mostly refers to a kind of anxiety experienced in interpersonal communicative settings, is noticeably quite relevant to foreign language contexts. So, communication apprehension obviously plays a large role in second/foreign language anxiety. Based on the idea of Tsiplakides and Keramida (2009), students who exhibit communication apprehension do not feel comfortable communicating in the target language in front of others, due to their limited knowledge of the language, especially in relation to speaking and listening skills. Further, as Horwitz, et al. (1986) claims people who are apprehensive speaking in groups are likely to be even in more trouble when doing so in a second/foreign language class, where in addition to feeling less in control of the communicative situation, they also may feel that their attempts at oral work are constantly being monitored. At the same time, Shamas, (2006) maintains that the emphasis on group work and oral presentation in the modern communicative classroom can be particularly exacerbating for students who have communication apprehension.

Oral communication anxiety or difficulty in speaking in groups and trouble in speaking in public or stage fright are all indicators of communication apprehension. The vital role of communication apprehension in creating foreign language anxiety is undeniable. Those who naturally have trouble speaking in group are likely to experience even greater difficulty speaking in a foreign language class where they feel less control over the communicative situation and their performance is constantly observed. Also, Koch and Terrell (1991) argued that more than half of their subjects considered oral presentations in front of the class as the most anxiety-producing activities. Horwitz, Horwitz and Cope (1986) indicated that students with high levels of anxiety were afraid of speaking in the foreign language and they had a deep sense of self-consciousness and 
International Journal of Applied Linguistics \& English Literature

ISSN 2200-3592 (Print), ISSN 2200-3452 (Online)

Vol. 1 No. 2; July 2012

viewed foreign language production in classroom as a test situation rather than as an opportunity for communication.

Among the other sources of language anxiety, one can consider the 'role of instructors' or teachers' concepts of language anxiety. Brandl (1987: cited in Onwuegbuzie et al., 1999: 220) declared that 'instructors' belief that their role is to correct rather than to facilitate students when they make mistakes exacerbates second/foreign language anxiety in students".

According to Young (1990: cited in Young 1991), the researchers also reported that students realize that some error corrections are necessary but they consistently report anxiety over responding incorrectly and looking or sounding 'dumb' or 'inept'.

Along with error correction, some teachers have been reported to be unwilling to encourage pair or group work because they are afraid of losing the control of the class and they have almost a teacher-centered view toward their own role in language classes, which finally results in creating anxiety among students, and as claimed by Young (1991) their role is more like a drill sergeants than a facilitator's which again contributes to learner's language anxiety.

\section{Methodology}

Once you take a look at the methodological approaches toward the investigation of language anxiety in the past, you will come across a heavy body of research which is done quantitatively in nature, and as Horwitz (1986) claims this type of research was unable to draw a clear picture of the relationship between anxiety and overall language acquisition, performance and proficiency. So, qualitative research is quite indispensable to explore language anxiety.

This research tries to investigate the factors that cause language anxiety for EFL learners from two different perspectives which are EFL learners' perspectives and EFL instructors' perspectives. The qualitative method in this research makes use of Exploratory Case Study procedure in the form of single case, single site and in accordance with purposive sampling approach in order to select information-rich cases. According to James Neill (2006), case study attempts to shed light on phenomena by studying in depth a single case example of the phenomena, and it can be an individual person, an event, a group, or an institution. Further, as Yin (2003) believes exploratory case study is a type of case study which is used to explore those situations in which the intervention being evaluated has no clear, single set of outcomes.

\subsection{Informants}

The first group of informants of this study consists of three Iranian college students majoring in the fields other than English at a university site in Malaysia and joining English conversation classes. They have learned English from middle school like ordinary Iranian students of the same age.

- Hadi is finishing the second semester ofComputer Engineering in MSc level. He is taking part in English conversation classes for second time in upper-intermediate level held at the campus of the university.

- Mahdi is putting an end to his fourth semester of Human Resource Development in MSc level. He is also taking part in English conversation classes for third time now studying in upper-intermediate level.

- Ashkan is about to finish his first semester of the course Economic Management in MSc level. He has studies English up to advanced level in two institutes in Iran and now is participating English conversation classes for the first time.

The second group of informants consists of three EFL highly experienced teachers who were chosen for the research and interview based on the principle of purposive sampling and their wealth of teaching experience.

- Reza has roughly 11 years of teaching experience in several places in Iran. he describes his students as usually engaged in activities to be prepared for EFL proficiency exams.

- Hesam has been teaching in different language institutes in Iran for almost 12 years. He mainly taught advanced level classes. He describes his students as mostly trying to be competitive with each other in class.

- $\quad$ Ali has taught English for about 15 years at different institutes and also at a university for undergraduate students in EFL course. He describes his students at language institutes as mostly hardworking and serious preparing for English proficiency test so that they could start or continue their academic education in better universities. 
International Journal of Applied Linguistics \& English Literature

ISSN 2200-3592 (Print), ISSN 2200-3452 (Online)

Vol. 1 No. 2; July 2012

\subsection{Data Collection}

The job of the researcher in this study is to record and interpret the informants' personal experiences in order to construct the knowledge of the case and provide thick description to each of the informants' unique cases. The researcher is the main instrument used to collect, analyze, and interpret the data.

\subsubsection{Interview}

This procedure adopting the inductive approach follows the data collection method of in-depth semi-structured interview. Interview is a method that elicits information and data by directly asking questions of informants. It has mainly the goal of entering the learners' world by understanding what they think or how they feel about things relevant to the issues under investigation. According to Patton (1987) it allows the researcher to gain a holistic understanding of informants' feelings, thoughts and intentions behind the observed behaviors and events.

As the nature of the individual interviews in this study was semi-structured, the researcher took advantage of both structured and unstructured techniques of individual interviews. He attempted to be a good listener, to learn from hisinformants, and to build trust and rapport with hisinformants.Also, to help the learners feel at home with the study questions, the examiner shared his personal stories of language anxiety related tooral performance with the learners in order to build rapport with them, and so they felt easy sharing their personal stories with him. Wolcott (1994) indicated that a researcher should connect the account with his or her personal experience to better achieve or understand himself or herself. Booth (1999) believes that it is important to be friendly and practice a non-threatening approach and openness in interviews such as providing informants time to think about the research questions and not being pushy.

As Patton (1990) declares the semi-structured interview has a fairly open framework, thereby allowing a great deal of flexibility in the kind of information that interviewees choose to give.

This flexibility during the interview according to Fraenkel\&Wallen (2003) is important in qualitative research because it allows the researcher to respond to the situation at hand while bringing up information that the researcher might not expect, potentially shedding a whole new insight onto a problem. In short, semi-structured interview can be considered as a fairly guided and relaxed discussion based around a predetermined topic.

Regarding interview settings with the learners, the interview site was the classroom, because the class was probably the most familiar place to them and thus they would feel most comfortable there. The interview was mainly conducted after classes. As for EFL teachers, they were interviewed in their own classrooms after instruction. It needs to be said that when necessary and agreed on by the interviewees, the second round of interview was conducted in order to gain additional and precise information and clarify any vague point.

The interview questions were typically simple with a logical order to help the interview go on naturally. Of course, the first job I did was to collect personal data for each of the informants in both learners' and teachers' groups (i.e. name, address, age, major, year in college, etc.). In learners' group I asked their backgrounds in English language learning (i.e., educational background, the length of learning English, current situations in which they learn English, etc.). I provided with each participant general clarifications of the purpose of the study. Afterward, based on the procedure of the study and in accordance with Foreign Language Classroom Anxiety Scale (FLCAS) developed by Horwitz (1986), I asked learner informants some questions in terms of when, how, and why they would feel anxious in their EFL learning. I used thisscale mainly for initiating and facilitating the conversations in the interviews, but not for gauging the degree of the learners' anxiety because the FLCAS was specifically designed to measure the student's foreign language anxiety quantitatively. I found many of the details in FLCAS, which contained severalforeign language situations that may incite anxiety in EFL learners, useful for drawing explanations from the interviewees, and also for putting forward further questions in the process of the interview. So, I asked general questions about their anxiety by using some of the statements from the FLCAS Scale. Such questions were: "Do you think you are an anxiety-prone person or not?", "Have you ever felt any anxiety or nervousness both in and outside of the classrooms?", "If so, when did you feel that way?", or "How did that feeling affect your physical and psychological well-being?" these questions could be extended in order to put forward some other questions contributing specifically to speaking anxiety, such as; "Which skill area do you think you face more anxiety than the other skill areas?", "Regarding speaking skill what do you usually do to cope with your feeling of anxiety?". Furthermore, there were some questions about the role of instructor in creating positive or negative feelings in students towards English classes, such as; "Have your instructors played a role in your feelings, either good or bad, about your foreign language classes? 
International Journal of Applied Linguistics \& English Literature

ISSN 2200-3592 (Print), ISSN 2200-3452 (Online)

Vol. 1 No. 2; July 2012

\begin{abstract}
4. Data Analysis
In correspondence with the principles of qualitative research (e.g. Merriam, 1988; Peirce, 1995), the researcher adopted aninductive approach in hisdealing with the transcribed data. According to Merriam (1998) analysis of qualitative study is to make sense of the data. Thus, the researchertranscribed the data comprehensively and wrote down the comments of the subjects in the relevant section; sections were divided on the basis of the two subject categories for identification purposes (EFL learners and EFL teachers). He, then, pulled the data apart and put it back together,read and reread the transcripts of the interviews to search for recurring themes and patterns of participant's responses.
\end{abstract}

After recognizing the common themes, the researcher determined the major and minor themes and analyzed the relations between the themes using a schematic model.Besides, the researcher in this study found his own understanding of the subject matter, and the research process developed in the meantime, contributing to the evolving research process, and proving the dynamic nature of the qualitative research process.

\title{
5. Findings and Discussion
}

While description of the three EFL learners' and three experienced teachers' perspectives on language anxiety and its possible effects on EFL learning answers the research question regarding their viewpoints on EFL language anxiety, it seems to be mostly verifying the findings offered by previous research on language anxiety. However, there were some differences found between the teachers' and students' insights on the role of anxiety in EFL learning environment.

\subsection{EFL Learners' Perspectives}

\subsubsection{Anxiety over inability to communicate in class}

These students' narratives mainly provided evidence that they did not participate in speaking activities, because they believed that they were not good at speaking and interacting with the others in class. Consequently, they feared that they can't communicate properly with the teacher and the other learners. Two of the informants claimed that they have experienced anxiety over speaking in class. Hadi, one of the learner informants, spoke as if this anxiety is as present now as it ever was. Mahdi, the second informant, spoke of continuing anxiety, though he felt it had rather decreased. The third informant, Ashkan, claimed to have entirely overcome this problem.

\subsubsection{Anxiety over producing perfect and faultless sentences}

Another source of fear of communication was the belief that they should produce perfect and faultless sentences. This finding seems consistent with Gregersen's (2003) suggestion that anxious learners tend to focus on form rather than content. Most of these anxious learners feared that mistakes in speaking activities would destroy their social image as capable learners.

\subsubsection{Anxiety over making errors in speaking}

Hadi and Mahdi claimed to be apprehensive about making errors when speaking in class, such as being "afraid to use the wrong words". Hadi claimed that he has no problem expressing his ideas in English, but at the same time, he admitted that he is "scared to speak the wrong words" in class, which limits his participation: Mostly, I have the ability to express my thoughts in English, but I am very careful when I speak. As a result, the number of times I speak in class is less than the other students because I am afraid to use the wrong words. Mahdi describes feelings created by his exaggerated focus on avoiding language mistakes: I always make lots of mistakes when I speak, and I don't like it. Because of that I use Persian when I'm not sure of what to say. In order to avoid mistakes, I also speak very slowly. Askan, the third informant, however; claimed to have gradually overcome his fear of speaking in class. He stated that:I am not that scared to speak now, and I won't think too much before I speak in comparison to the past, when I just came here to study. I was very scared! I was very scared to use the wrong words!

\subsubsection{Fear of being called on}

Hadiand Mahdi clearly stated their fear of being called on in class. They both think that they are unable to overcome this problem. At other times, Hadi claimed to be worried only about his grades and results and about bringing to an end his college degree.Yet, some of his statements suggest discomfort with classroom situations. Hadi gets anxious and nervous when the professors ask students to answer questions on the spot or require students to participate. He described feeling apprehensive about speaking in class at that time, especially when the professor called on him: At first I couldn't adjust myself with the class . . especially when teachers asked me to take part and express my opinion in there. I would think, Oh! It's my turn to speak! . . I was very afraid to be asked to express my own opinion.

Page $\mid 158$ 
International Journal of Applied Linguistics \& English Literature

ISSN 2200-3592 (Print), ISSN 2200-3452 (Online)

Vol. 1 No. 2; July 2012

\subsubsection{Avoiding asking professor questions}

All three informants have problems asking professors questions. They avoid asking professors questions, where Hadi is afraid of asking professors questions, and he does so in order to earn a good participation grade. Even thoughhe has problems or questions about the content of the course, he does not try to ask his instructors questions: because of being passive, I usually tried not to ask my instructors after classes. So far, this has been my major problem, perhaps, because of being shy. Mahdi claims that in the case of having no other choice he referred to the instructor to ask questions, but in most cases the classmates were preferred by him to be questioned. He said that he asked himself if it is a good idea to ask the professor "such a small, unimportant question!" Ashkan, on the other hand, feels a bit different about the issue. He says: since I don't feel ready enough to ask teacher questions in class, I prefer to put questions forward after the other students leave the class and there is no one around, but again I feel unable to express myself clearly to the teacher. It seems that when I am speaking, it gets difficult for me to be relaxed and out of stress.

\subsection{EFL Teachers' Perspectives}

In conducting the semi-structured interview from three EFL teacher informants, the six questions of Ohata (2005) from teachers are considered to startthe interviews with. These questions are then followed by some more in-depth questions in order to bring the interviews to the saturation level. Regarding the views of teachers to the role language anxiety plays in EFL learners' speaking skills, the three informants almost admitted the possible negative effect of it. This supports the current researchers' perceptions toward language anxiety, such as Ohata (2005) who maintains that language learning anxiety is to be rated significantly higher than other class anxieties.

At the same time, however, all these teachers claimed that some of the language anxiety experiences could have a positive or facilitating effect on EFL learning. Hesam, the second informant teacher, has a bit stronger view towards the positive role anxiety may also play by saying: It might be a reward, to me. However, the level of anxiety should be optimal. Although some believe it may hinder learning, I tend to say having to some extent it will foster learning.Reza, the first informant has almost a negative view towards the role of anxiety by saying: Anxiety can hinder or even stop L2 acquisition. Ali, the third informant,

on the other hand,admitting the positive role of anxiety in some occasions in the class, tries to be cautious about the undesirable effect of it by saying: High amount of anxiety is terribly bad especially for junior students and first levels of senior students. Mostly the perception of the teacher informants in this study is in accordance with the theoretical ideas suggested by many anxiety researchers, andit is believed that as Omaggio (1986) declares some 'edge' is necessary in language learning. Yet according to Scovel (1991), whereas facilitating anxiety produces positive effects on learners' performance, too much anxiety may cause a poor performance.

Concerning the amount of anxiety in four skill areas, the three informants have consensus that speaking among the skills is by nature the most anxiety provoking skill, however; Reza believes that listening skill, too, is considered to be causing anxiety in class because of its simultaneity. He says: Especially when the learner is faced up with a series of questions while listening in the process of instruction in class, it gets difficult for him to keep the track of listening and comprehend the conversations and the events in the listening at the same time. This causes him to lose concentration and become worried and stressful. Ali also considers the issues like lack of background knowledge and being less exposed to language as the contributing factors to anxiety in speaking.

Is response to the question of manifestation of anxiety in their students, the informants all declared that there are some physical changes along with less comprehension and less interaction occurring in their students whenever there exists an anxiety-provoking situation.

Concerning the technics and measures used to reduce language anxiety in the classroom, the three informants emphasized on the use of learner-centered approach in encouraging the students to do pair and group work activities and creating a comfortable class setting. Reza talked about making a lively atmosphere in the class by using games, and not focusing on the student who doesn't feel ok and looks stressful at that moment. He continued: I think it is very important that while those students are speaking try to encourage and acclaim them in order to remove the affective filter of anxiety and push them delicately and gradually to take more part in interactions in class. Ali, on the other hand, put emphasis on need analysis of students and maintains that it is of crucial importance to take into account needs and local values of students in classroom interactions. He continues by saying: Communicative technics along with these values, if taken into consideration, play an important role in creating a relaxed, desirable and comfortable environment for students in EFL classes.

One final viewpoint of EFL teacher informants was about the relationship between these technics and their philosophy of teaching. All informants agreed that their teaching philosophy determines to a great extent the Page | 159 


\section{International Journal of Applied Linguistics \& English Literature}

ISSN 2200-3592 (Print), ISSN 2200-3452 (Online)

Vol. 1 No. 2; July 2012

level of anxiety in EFL students in class. This brought up the issue of the role a teacher must assume for himself to play in the class. Reza, in this regard, believes that a teacher should take the role of a facilitator in class other than showing authority over the students. Hesam, the second informant, referring to the same points claims that a friendly manner of a teacher in non-threatening environment of the class results in building trust between teacher and students. He says: If such trust is built in the classroom, students will feel more committed to the tasks they are supposed to do in the class and they will try to take more active roles in speaking and discussion activities.

After all, the various manifestations and signs of anxiety that the informants observed in their students seem to agree with what has been stated in the previous research on language anxiety. This shows that experienced teachers' perceptions of anxious behaviors in students are exact and sound enough to identify the signs of student anxiety.

Also, based on the teacher informants' views on language anxiety, it seems to be fairly in accord with their own philosophy of teaching and their assumptions about the role of the language teacher. The common point shared by the informants about the role of the language teacher was that the teacher's role should be that of facilitator, counselor, or motivator.

According to Burden (2004), if teachers help learners to recognize their fears and realize that anxiety episodes are transient, students can learn to interpret such situations in realistic ways, and thus may choose to approach, rather than avoid, situations that demand participation.

Further, Burden (2004) declares that the teacher can alleviate anxiety and foster a less confrontational atmosphere by encouraging pair work, group activities and scaffolding for mutual support and reassurance, the very things highlighted by teacher informants of this research.

\section{Conclusion}

Though this research has provided valuable insights into language anxiety from the students' and teachers' perspective, the phenomenon, as declared by Ohata (2005), because of its complex and multi-dimensional nature, still requires further investigation from a variety of perspectives or approaches. This research, done through in-depth semi-structured interviews with three experienced EFL teachers along with three EFL learners, is considered one of such attempts to provide some alternative insights on language anxiety from a different perspective. The results of the study showed that language anxiety could affect the speaking skills of learners by lowering the quality of oral performance as the anxiety increases.

Further, as is clearly shown by the interview results, many of the accounts from the informants seem to generally validate the findings offered by earlier research on language anxiety, but there are also some differences or gaps between the EFL teachers' and learners' perceptions on the role of anxiety in EFL classroom settings. As maintained by Ohata (2005), although the teachers' efforts to be a bit more aware of the students' anxiety might not always come together with the students' actual perceptions, the teacher's very attitudes of trying to understand the students' affective needs can provide a basis for creating a comfortable and encouraging environment in the classroom. And finally, teachers need to assume the role of the researcher in their own classrooms. Before using strategies to help students overcome foreign language speaking anxiety, they should get to know their students, and shed light into the causes that underlie learners' low performance and their reluctance to participate in speaking activities.

\subsection{Recommendations}

Based on the explorations done on foreign language anxiety, there are some factors that, if taken into account, lead to reducing communication apprehension and speaking anxiety, and these aspects facilitate establishing a learning community that according to Alderman (2004: cited in Tsiplakides, Keramida, 2009) provides the environment for 'optimal motivation' and a supportive classroom atmosphere. So, in order to answer the research question concerning the strategies used by EFL teachers and learners in dealing with language anxiety, the following suggestions are provided:

A set of classroom rules and norms can be established with the students. For instance; making fun of a wrong answer is unacceptable, and errors could be considered a natural part of learning a foreign language, so as Dörnyei (2001: cited in Tsiplakides, Keramida, 2009) states students could be encouraged to ask for help without running the risk of embarrassment. Further, since direct correction in speaking skill can challenge students' confidence, indirect correction is strongly emphasized. In order to alleviate communication apprehension and for active participation of learners in the classroom discussion, it should be ensured that they are provided friendly, informal and learning-supportive environments.According to Frymier (1993: cited in Tsiplakides, Keramida,

Page $\mid 160$ 


\section{International Journal of Applied Linguistics \& English Literature}

ISSN 2200-3592 (Print), ISSN 2200-3452 (Online)

Vol. 1 No. 2; July 2012

2009) in another step to reduce anxiety and influence positively on motivation to learn, both verbal (use of humor, use of students' first names) and nonverbal (eye contact, positive gestures) types of immediacy behavior can be employed. Finally, it seems necessary that EFL teachers experience specific training courses on language anxiety in order to become aware of the sources of it and the strategies to alleviate it in EFL classes.

\section{References}

Backman, N. (1976). Two measures of affective factors as they relate to progress in adult second language learning.Working Papers in Bilingualism, 10, 100-22.

Booth, S. (1999). Researching health and homelessness: Methodological challenges for researchers working with a vulnerable, hard to reach transient population.Australian Journal of Primary Health-Interchange, 5(3), 76-81.

Burden, P. (2004).The Teacher as Facilitator: Reducing anxiety in the EFL university classroom. JALT Hokkaido Journal, 8, 3-18.

Caprio, M. (1987). University students and second language learning: A look at purpose and attitude. Academia: Literature and Language, 42, 23-36.

Clément, R., Gardner, R. C., \&Smythe, P. C. (1980). Social and individual factors in second language acquisition.Canadian Journal of Behavioural Science, 12, 293-302.

Fraenkel, J. R., \&Wallen, N. E. (2003). How to design and evaluate research in education(5th ed.). Boston: McGraw Hill.

Gardner, R. (1985). Social psychology and second language learning: the role of attitude and motivation. London: Edward Arnold.

Gardner, R., P. Tremblay \& Masgoret, A-M. (1997).Towards a full model of second language learning: an empirical investigation.The Modern Language Journal, 81(3): 344-362.

Gregersen, T. S. (2003). To Err Is Human: A Reminder to Teachers of Language-Anxious Students. Foreign Language Annals, 36(1), 25-32.

Hashimoto, Y. (2002). Motivation and willingness to communicate as predictors of L2 Use: The Japanese ESL context. Second Language Studies, 20, 29-70.

Horwitz, E. K. (2001). Language Anxiety and Achievement.Annual Review of Applied Linguistics, 21, 112-126.

Horwitz, E.K., Horwitz, M.B., \& Cope, J. (1986).Foreign Language Classroom Anxiety.The Modern Language Journal,70, 125-132.

Koch, A. S., \& Terrell, T. D. (1991).Affective reactions of foreign language students to natural approach activities and teaching techniques.In Elaine K. Horwitz\& Dolly J. Young (Eds.).Language anxiety: From theory and research to classroom implications, 109-126. Englewood Cliffs, NJ: Prentice Hall.

Kota, O, (2005).Language Anxiety from the Teachers' Perspective: Interviews with Seven Experienced ESL/EFL Teachers. Journal of Language and Learning 1(3), 133-155.

MacIntyre, P. D. (1995). How Does Anxiety Affect Second Language Learning.The Modern Language Journal, 79,245-248.

McCroskey, J. C. (1977). Classroom consequences of communication apprehension.Communication Education, $26,27-33$

McCroskey, J. C. (1987). The WTC as a predictor of classroom participation.Communication Research Reports, 4, 47-50.

Merriam, S. B. (1988). Case study research in education: A qualitative approach. San Francisco: Jossey-Bass.

Neil, J. (2006).Qualitative Research 1: Types \& Methods: Lecture Notes,Analysis of Professional Literature; http://wilderdom.com/OEcourses.

Omaggio, A. C. 1986. Teaching language in context: Proficiency-oriented instruction. Boston: Heinle and Heinle.

Onwuegbuzie, A. J., Bailey, P., \& Daley, C. E. (1999).Factors associated with foreign language anxiety.Applied Psycholinguistics, 20, 217-239.

Page | 161 
International Journal of Applied Linguistics \& English Literature

ISSN 2200-3592 (Print), ISSN 2200-3452 (Online)

Vol. 1 No. 2; July 2012

Patton, M. Q. (1987). How to use qualitative methods in evaluation. Newbury Park, CA: Sage.

Patton, M. (1990).Qualitative evaluation and research methods (2nd ed.). Newbury Park, CA: Sage.

Peirce, B. N. (1995). The theory of methodology in qualitative research. TESOL Quarterly, 29, 569-576.

Scovel , T. (1978). The Effect of Affect.Language Learning, 28.

Scovel, T. (1991). The Effect of Affect on Foreign Language Learning: A Review of the Anxiety Research in E. K. Horwitz and D. J. Young, Language Anxiety, 101-108. Englewood Cliffs, NJ: Prentice Hall.

Shamas, A. (2006). The Use of Computerized Pronunciation Practice in the Reduction of Foreign Language Classroom Anxiety. Unpublished Ph.D. Thesis, The Florida State University.

Tsiplakides I., Keramida A. (2009). Helping Students Overcome Foreign Language Speaking Anxiety in the English Classroom: Theoretical Issues and Practical Recommendations.International Education Studies, 2(4), 39-44.

Wolcott, H. F. (1994). Transforming qualitative data: Description, analysis, and interpretation. Thousand Oaks, CA: Sage.

Yin, R. K. (2003).Case study research: Design and methods (3rd Ed.). Thousand Oaks, CA: Sage.

Young, D. J. (1991).Creating a low-anxiety classroom environment. What does language anxiety research suggest? The Modern Language Journal, 75(4), 426-439.

Young, D. J. (1992).Language anxiety from the foreign language specialist's perspective: interview with Krashen, Omaggio Hadley, Terrell, and Rardin..Foreign Language Annals, 25,157-172. 